\title{
EVALUATE THE CAPABILITY OF LANDSAT8 OPERATIONAL LAND IMAGER FOR SHORELINE CHANGE DETECTION /INLAND WATER STUDIES
}

\author{
W. Pervez ${ }^{\text {a }}$, S. A. Khan ${ }^{\text {b }}$, Ejaz Hussain ${ }^{\text {c }}$, Faisal Amir ${ }^{\text {d }}$, M.A. Maud ${ }^{\text {e }}$ \\ a National University of Sciences and Technology Islamabad, Pakistan - wasim_pervaiz@pnec.nust.edu.pk \\ ${ }^{\mathrm{b}}$ National University of Sciences and Technology Islamabad, Pakistan - shoabak@ceme.nust.edu.pk \\ ${ }^{\mathrm{c}}$ National University of Sciences and Technology Islamabad, Pakistan- ejaz@igis.nust.edu.pk \\ d National University of Sciences and Technology Islamabad, Pakistan- faisalamir@pnec.nust.edu.pk \\ ${ }^{\mathrm{e}}$ National University of Sciences and Technology Islamabad, Pakistan- mamaud@uet.edu.pk
}

Commission VI, WG VI/4

KEY WORDS: Change Detection Analysis, Satellite Image Processing, Remote Sensing, Imaging Sciences, Operational Land Imager

\begin{abstract}
:
This paper explored the capability of Landsat-8 Operational Land Imager (OLI) for post classification change detection analysis and mapping application because of its enhanced features from previous Landsat series. The OLI support vector machine (SVM) classified data was successfully classified with regard to all six test classes (i.e., open land, residential land, forest, scrub land, reservoir water and waterway). The OLI SVM-classified data for the four seasons (i.e. winter, spring, summer and autumn seasons) were used for change detection analysis of six situations; situation1: winter to spring seasonal change detection resulted reduction in reservoir water mapping and increases of scrub land; situation 2: winter to summer seasonal change detection resulted increase in dam water mapping and increase of scrub land. winter to summer which resulted reduction in dam water mapping and increase of vegetation; situation 3: winter to summer seasonal change detection resulted increase in increase in open land mapping; situation 4 : spring to summer seasonal change detection resulted reduction of vegetation and shallow water and increase of open land and reservoir water; situation; 5: spring to autumn seasonal change detection resulted increase of reservoir water and open land; and Situation 6: summer to autumn seasonal change detection resulted increase of open land. OLI SVM classified data found suitable for post classification change detection analysis due to its resulted higher overall accuracy and kappa coefficient.
\end{abstract}

\section{INTRODUCTION}

Remote sensing provides temporal classification of inland water studies (Gardelle et al., 2010; Prigent et al., 2012; Zhang et al., 2015). Landsat-8 Operational Land Imager; OLI due to better technical design is more appropriate for mapping application as compared to previous Landsat series (Irons J. R., Dwyer J. L. Barsi, J. A., 2012; Markham, B. L. et al., 2010; Pehlevan, N., Schott, J. R., 2011; U.S Geological Survey, 2012). Landsat-8 OLI provides efficient mapping application than Landsat-7 and earlier series (Czapla-Myers, et al., 2015; Flood, N., 2014; Jiag, P., Li, Feng, Z., 2014; Knight, E., Kvaran, G., 2014; Ke, Y., et al., 2015; Pervez, W., 2016; Morfitt., R., 2015; Markham, B., 2014; Roy D., et al., 2014. This paper presents a post classification change detection study of Landsat-8 Operational Land Imager (OLI) data classified by SVM of the study area for the four seasons. Change detection methods employed depends upon its application (Almutairi, A., Warner, T. A., 2010; Hecheltjen, A., Thonfeld, F., Menz, G., 2014. The objective of the paper was: (i) to evaluate OLI data using SVM classification for the four seasons (i.e. winter, spring, summer and autumn seasons) ; (ii) to evaluate seasonal change detection analysis of six situations from the four season OLI data.

\section{STUDY AREA AND DATA SETS}

This paper describes seasonal change detection analysis of OLI data using SVM classifier for the four seasons. OLI data parameters of the study area are shown in Table 1.

Table 1 : Imaging geometry conditions and scene center latitudes and longitudes for Landsat-8 OLI

\begin{tabular}{|c|c|c|c|c|}
\hline & $\begin{array}{c}23 \mathrm{Nov} \\
2015\end{array}$ & $\begin{array}{c}30 \mathrm{Mar} \\
2015\end{array}$ & $\begin{array}{c}20 \mathrm{Jul} \\
2016\end{array}$ & $\begin{array}{c}8 \text { Oct } \\
2016\end{array}$ \\
\hline $\begin{array}{c}\text { Sensor } \\
\text { Altitude }\end{array}$ & $705 \mathrm{~km}$ & $705 \mathrm{~km}$ & $705 \mathrm{~km}$ & $705 \mathrm{~km}$ \\
\hline $\begin{array}{c}\text { Off- } \\
\text { nadir/Nadir }\end{array}$ & Nadir & Nadir & Nadir & Nadir \\
\hline $\begin{array}{c}\text { Sun } \\
\text { Azimuth }\end{array}$ & $159.83^{\circ}$ & $139.19^{\circ}$ & $115.7^{\circ}$ & $152.67^{\circ}$ \\
\hline $\begin{array}{c}\text { Sun } \\
\text { Elevation }\end{array}$ & $33.83^{\circ}$ & $53.88^{\circ}$ & $65.92^{\circ}$ & $47.08^{\circ}$ \\
\hline $\begin{array}{c}\text { Scene center } \\
\text { latitude }\end{array}$ & $33.10^{\circ}$ & $33.10^{\circ}$ & $33.10^{\circ}$ & $33.10^{\circ}$ \\
\hline $\begin{array}{c}\text { Scene center } \\
\text { longitude }\end{array}$ & $72.52^{\circ}$ & $72.52^{\circ}$ & $72.53^{\circ}$ & $72.53^{\circ}$ \\
\hline
\end{tabular}




\section{RESULTS AND DISCUSSION}

\subsection{OLI Data Classified using SVM Classifier}

OLI data was classified using SVM classifier. Figure 1 shows OLI data of the four seasons (i.e. winter, spring, summer, autumn) classified using SVM classifier.

\subsection{Experimental Setup}

Fol values were set for experimental setup:

Kernel parameter gamma $(\gamma)=1 /$ No of bands $=0.143$

Penalty parameter $\mathrm{C}=100$

pyramid parameter $=$ zero

classification probability threshold $=$ zero

High resolution imagery is used for establishing region of interest.
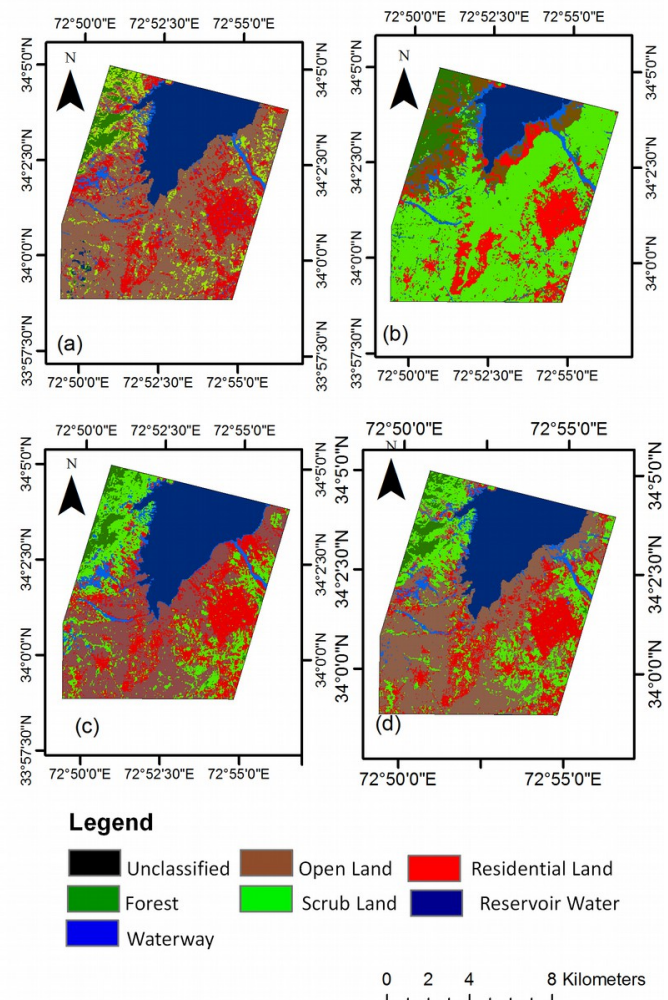

Figure 1. OLI data classified by SVM (a) winter (23 November, 2015), (b) spring (30 March, 2016) (c) summer (20 July, 2016), and (d) autumn (8 October, 2016)

\subsection{Seasonal Change Detection from Winter to Spring}

Change detection matrix (Table 2) from winter to spring shows decrease of spatial mapping of Open Land $64.37 \%$, forest $80.96 \%$, Residential land $30.79 \%$ and increase of waterway $40.08 \%$, scrub land $170.01 \%$ and reservoir water $128.04 \%$. Figure 2 shows a change of category from reservoir water to waterway, reservoir water to Scrub land, and reservoir water to open land. Similarly, a change of category from open land to scrub land, scrub land to forest, residential land to scrub land and residential land to open land resulted increase of bushes in spring from winter. Similarly change of category from forest to reservoir water and scrub land to open land also resulted due to seasonal change. Change detection from winter to spring resulted reduction in reservoir water mapping and increases of scrub land.

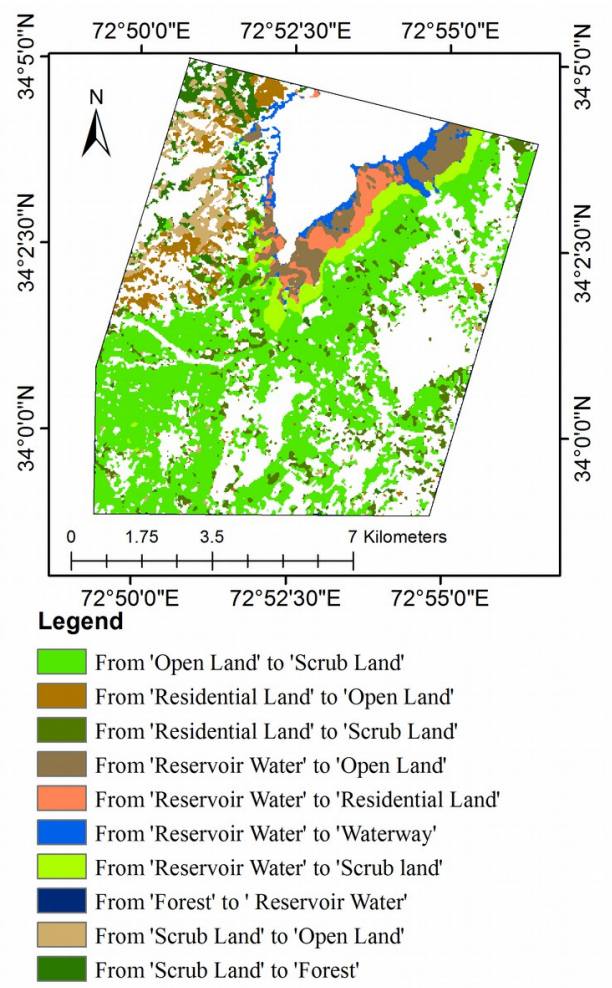

Figure 2. Winter to spring seasonal change detection

\subsection{Seasonal Change Detection from Winter to Summer}

Change detection matrix (Table 3) shows decrease of spatial mapping of open land $8.3 \%$, residential land $7.3 \%$, forest $90.27 \%$, scrub land $1.05 \%$, and increase of reservoir water $198.35 \%$, waterway $18.15 \%$. Figure 3 shows a change of category from open land to scrub land, residential land to scrub land resulted increases of vegetation in summer compared to winter. A change of category from open land to residential land, from residential land to open land, from scrub land to open land and from scrub land to residential land is due to seasonal change. Change detection from winter to summer resulted increase in dam water mapping and increase of scrub land. 


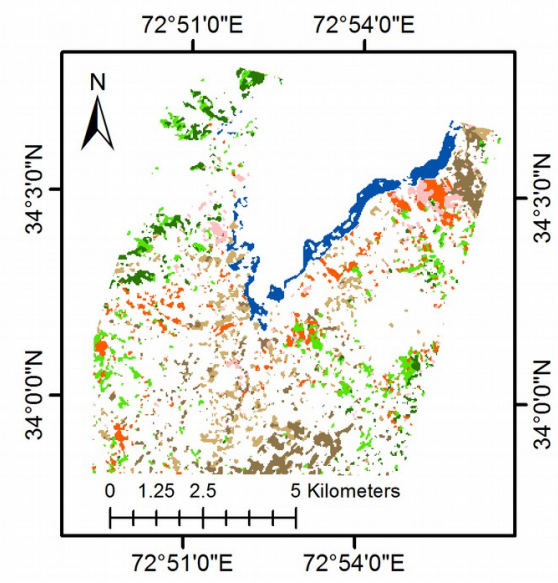

\section{Legend}

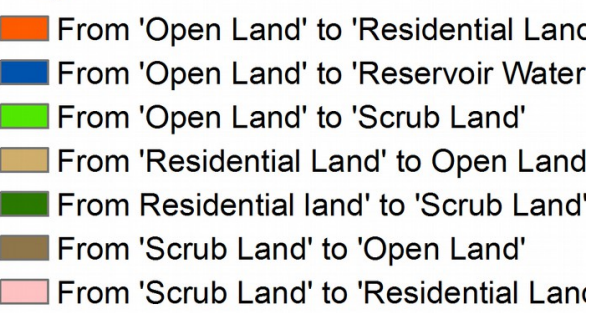

Figure 3. Winter to summer seasonal change detection

\subsection{Seasonal Change Detection from Winter to Autumn}

Change detection matrix (Table 4) from winter to autumn shows decrease of spatial mapping of forest $91.5 \%$, residential land $19.8 \%$, scrub land $17.1 \%$ and increase of open land $15.1 \%$, reservoir water $182.7 \%$ waterway $5.9 \%$. Figure 4 shows category changes scrub land to open land and residential land to open land with increase in open land. Similarly, small category changes from open land to scrub land, scrub land to open land and open land to residential land resulted due to seasonal change. Change detection from winter to summer resulted increase in increase in open land mapping.

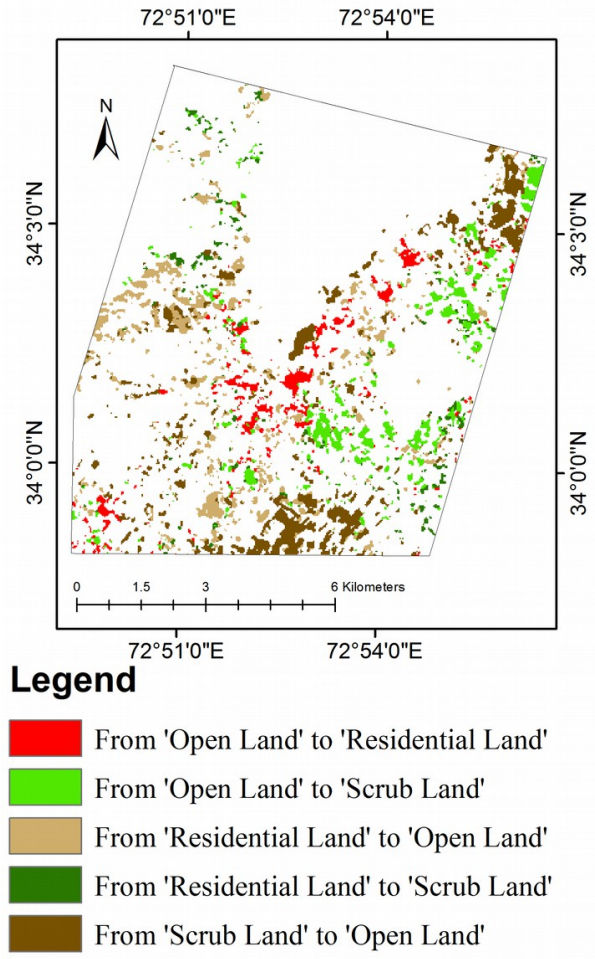

Figure 4. Winter to autumn seasonal change detection

\subsection{Seasonal Change Detection from Spring to Summer}

Change detection matrix (Table 5) from spring to summer shows decrease of spatial mapping of forest $48.8 \%$, waterway $15.6 \%$, scrub land $63.4 \%$ and increase of open land $157.4 \%$, reservoir water $30.8 \%$ and residential land $33.8 \%$. Figure 5 shows category changes from residential land to open land, scrub land to open land which resulted increase of open land. Similarly category change from open land to reservoir land, residential land to reservoir land, waterway to reservoir land and scrub land to reservoir land resulted increase of reservoir water. A change of category from opens land to scrub land, forest to scrub land and scrub land to residential land resulted due to seasonal change. Change detection from spring to summer resulted reduction of vegetation and shallow water and increase of open land and reservoir water. 


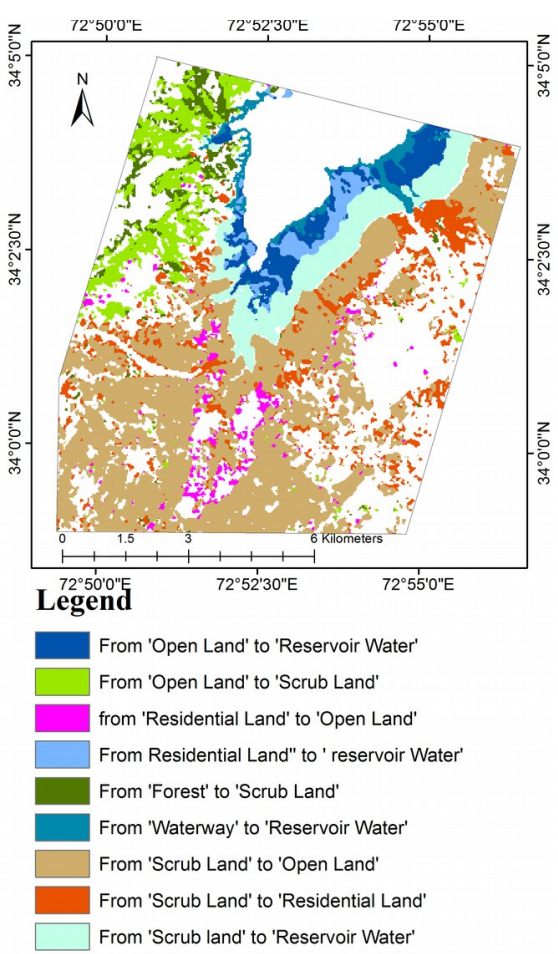

Figure 5. Spring to summer seasonal change detection

\subsection{Seasonal Change Detection from Spring to Autumn}

Change detection matrix (Table 6) from spring to autumn shows decrease of spatial distribution of forest $55.6 \%$, waterway $24.3 \%$, scrub land $65.6 \%$ and increase of open land $223 \%$, reservoir water $23.9 \%$ and residential land $15.8 \%$. Figure 6 shows category changes with increases in dam water mapping from waterway to reservoir water, open land to reservoir water, residential land to reservoir land, scrub land to reservoir land resulted increase of reservoir water. Similarly change of category from scrub land to open land and forest to open land resulted increase of open land. Small category changes from open land to scrub land and forest to scrub land resulted due to seasonal change. Seasonal change detection from spring to autumn resulted increase of reservoir water and open land.
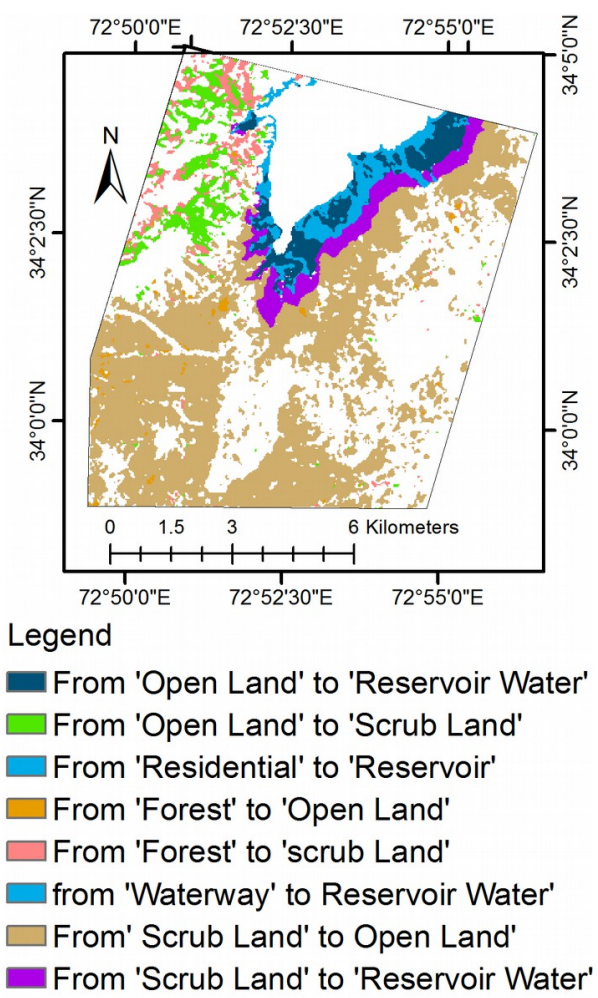

Figure 6. Spring to autumn seasonal change detection

\subsection{Seasonal Change Detection from Summer to Autumn}

Change detection matrix from Summer to Autumn shows (Table 7) decrease of spatial mapping of residential land $13.5 \%$, reservoir water $5.2 \%$, forest $13.2 \%$, waterway $10.3 \%$ scrub land $6.1 \%$, and increase of open land $25.5 \%$. Figure 7 shows a category changes from residential land to open land, from reservoir water to open land, from waterway to open land, from scrub land to open land which resulted increase in open land. Change of category from open land to scrub land, residential land to open land resulted due to seasonal change. Small change from open land to residential land resulted due to lack of vegetation cover the buildings and some misclassification. Seasonal change detection from summer to autumn resulted increase of open land. 


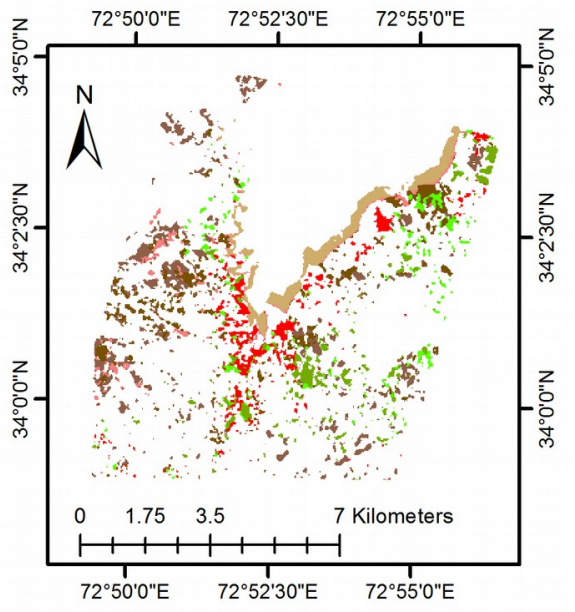

\section{Legend}

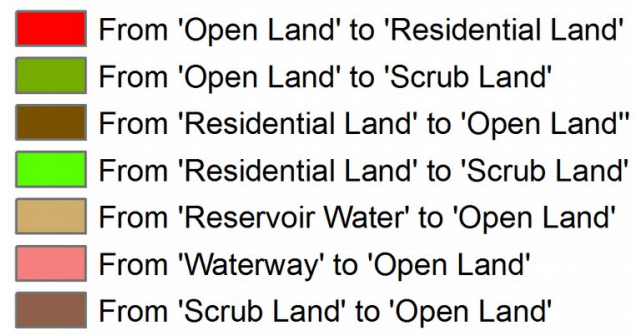

Figure 7. Summer to autumn seasonal change detection
95.0\% (Kappa coefficient $=0.94), \quad 92.8 \% \quad$ (Kappa coefficient $=0.91) \quad$ and $\quad 92.85 \% \quad$ (Kappa coefficient $=0.90$ ) respectively. Thus OLI data is appropriate for post classification change detection analysis.

\section{CONCLUSIONS}

The results of this study established the potential utility of OLI data change detection analysis The OLI SVM classified data was classified with regard to all six test classes (i.e., open land, residential land, forest, scrub land, reservoir water and waterway). OLI classified data using SVM classifier resulted higher overall accuracy (more than 91\%) and kappa coefficient and thus appropriate for change detection analysis. The OLI SVM-classified data for the winter, spring, summer and autumn seasons were used for change detection analysis of six situations. Situation 1: seasonal change detection from winter to spring resulted reduction in reservoir water mapping and increases of scrub land. Situation 2: seasonal change detection from winter to summer resulted increase in dam water mapping and increase of scrub land. Situation 3: seasonal change detection from winter to summer resulted increase in increase in open land mapping. Situation 4 : seasonal change detection from spring to summer resulted reduction of vegetation and shallow water and increase of open land and reservoir water. Situation 5: seasonal change detection from spring to autumn resulted increase of reservoir water and open land. Situation 6: seasonal change detection from summer to autumn resulted increase of open land. These results established that the new OLI technology, with its higher overall accuracy suitable for post classification change detection analysis.

\section{CLASSIFICATION ACCURACY ASSESSMENT}

The overall classification accuracy assessment using confusion matrix for OLI SVM classified data of winter, spring, summer and autumn season data were $96.7 \%$ (Kappa coefficient $=0.96$ ),

Table 2: Winter to Spring Season Change Detection Percentage

\begin{tabular}{|l|l|l|l|l|l|l|}
\hline Class & Open Land & $\begin{array}{l}\text { Reservoir } \\
\text { Water }\end{array}$ & Forest & Waterway & $\begin{array}{l}\text { Scrub } \\
\text { Land }\end{array}$ & $\begin{array}{l}\text { Residential } \\
\text { Land }\end{array}$ \\
\hline Open Land & 4.5 & 17.5 & 0.1 & 15.7 & 15.8 & 15.2 \\
\hline Reservoir Water & 0 & 48.1 & 91.3 & 0 & 0 & 0 \\
\hline Forest & 2.6 & 0.6 & 8.0 & 3.6 & 14.1 & 0.8 \\
\hline Waterway & 1.6 & 9.0 & 0 & 51.5 & 1.5 & 3.6 \\
\hline Scrub Land & 88.7 & 14.8 & 0.3 & 11.8 & 63.9 & 29.7 \\
\hline Residential Land & 2.3 & 9.6 & 0 & 17.1 & 4.5 & 50.4 \\
\hline Class Total & 100 & 100 & 100 & 100 & 100 & 100 \\
\hline Class Changes & 95.4 & 51.8 & 91.9 & 48.4 & 36.0 & 49.5 \\
\hline Image Difference & -64.4 & 128.0 & -80.9 & 40.0 & 170.0 & -30.7 \\
\hline
\end{tabular}


The International Archives of the Photogrammetry, Remote Sensing and Spatial Information Sciences, Volume XLII-5/W1, 2017 GEOMATICS \& RESTORATION - Conservation of Cultural Heritage in the Digital Era, 22-24 May 2017, Florence, Italy

Table 3: Winter to Summer Season Change Detection Percentage

\begin{tabular}{|l|l|l|l|l|l|l|}
\hline Class & Open Land & $\begin{array}{l}\text { Reservoir } \\
\text { Water }\end{array}$ & Forest & Waterway & $\begin{array}{l}\text { Scrub } \\
\text { Land }\end{array}$ & $\begin{array}{l}\text { Residential } \\
\text { Land }\end{array}$ \\
\hline Open Land & 60.8 & 0.3 & 0.1 & 6.6 & 23.9 & 24.1 \\
\hline Reservoir Water & 7.2 & 99.4 & 91.3 & 9.3 & 3.3 & 0.7 \\
\hline Forest & 0.1 & 0 & 6.6 & 0 & 5.4 & 0 \\
\hline Waterway & 3.9 & 0 & 0.1 & 53.7 & 0.9 & 4.0 \\
\hline Scrub Land & 13.5 & .1 & 1.66 & 7.2 & 52.8 & 15.4 \\
\hline Residential Land & 14.1 & 0.1 & 0.1 & 22.9 & 13.4 & 55.5 \\
\hline Class Total & 100 & 100 & 100 & 100 & 100 & 100 \\
\hline Class Changes & 39.1 & 0.5 & 93.3 & 46.2 & 47.1 & 44.4 \\
\hline Image Difference & -8.2 & 198.3 & -90.2 & 18.1 & -1.0 & -7.3 \\
\hline
\end{tabular}


Table 4: Winter to Autumn Season Change Detection Percentage

\begin{tabular}{|l|l|l|l|l|l|l|}
\hline Class & Open Land & $\begin{array}{l}\text { Reservoir } \\
\text { Water }\end{array}$ & Forest & Waterway & $\begin{array}{l}\text { Scrub } \\
\text { Land }\end{array}$ & $\begin{array}{l}\text { Residential } \\
\text { Land }\end{array}$ \\
\hline Open Land & 73.7 & 0.4 & 0.1 & 14.9 & 34.2 & 29.3 \\
\hline Reservoir Water & 1.7 & 99.4 & 91.3 & 1.5 & 0 & 0 \\
\hline Forest & 0 & 0 & 7.4 & 0 & 1.9 & 0 \\
\hline Waterway & 2.6 & 0 & 0 & 56.8 & 1.4 & 3.2 \\
\hline Scrub Land & 12.2 & 0 & 0.9 & 3.9 & 55.6 & 11.4 \\
\hline Residential Land & 9.5 & 0 & 0 & 22.7 & 6.7 & 55.9 \\
\hline Class Total & 100 & 100 & 100 & 100 & 100 & 100 \\
\hline Class Changes & 26.2 & 0.5 & 92.5 & 43.1 & 44.3 & 44.0 \\
\hline Image Difference & 15.0 & 182 & -91.5 & 5.9 & -7.1 & -19.8 \\
\hline
\end{tabular}

Table 5: Spring to Summer Season Change Detection Percentage

\begin{tabular}{|l|l|l|l|l|l|l|}
\hline Class & Open Land & $\begin{array}{l}\text { Reservoir } \\
\text { Water }\end{array}$ & Forest & Waterway & $\begin{array}{l}\text { Scrub } \\
\text { Land }\end{array}$ & $\begin{array}{l}\text { Residential } \\
\text { Land }\end{array}$ \\
\hline Open Land & 5.2 & 0 & 6.0 & 3.7 & 52.1 & 14.9 \\
\hline Reservoir Water & 27.9 & 99.9 & 2.3 & 36.9 & 11.4 & 12.1 \\
\hline Forest & 1.1 & 0 & 45.6 & 0 & 0.4 & 0 \\
\hline Waterway & 10.3 & 0 & 4.5 & 33.6 & 2.0 & 0.5 \\
\hline Scrub Land & 43.5 & 0 & 37.2 & 12.3 & 18.6 & 5.5 \\
\hline Residential Land & 11.7 & 0 & 4.7 & 13.3 & 15.1 & 66.7 \\
\hline Class Total & 100 & 100 & 100 & 100 & 100 & 100 \\
\hline Class Changes & 94.7 & 0 & 54.3 & 66.3 & 81.3 & 33.2 \\
\hline Image Difference & 157.3 & 30.8 & -48.8 & -15.6 & -63.3 & 33.8 \\
\hline
\end{tabular}

Table 6: Spring to Autumn Season Change Detection Percentage

\begin{tabular}{|l|l|l|l|l|l|l|}
\hline Class & Open Land & $\begin{array}{l}\text { Reservoir } \\
\text { Water }\end{array}$ & Forest & Waterway & $\begin{array}{l}\text { Scrub } \\
\text { Land }\end{array}$ & $\begin{array}{l}\text { Residential } \\
\text { Land }\end{array}$ \\
\hline Open Land & 24.4 & 0 & 14.0 & 9.6 & 61.1 & 14.8 \\
\hline Reservoir Water & 27.8 & 99.82 & 1.7 & 32.6 & 6.4 & 11.9 \\
\hline Forest & 0 & 0 & 42.8 & 0 & 0 & 0 \\
\hline Waterway & 7.5 & 0 & 2.5 & 33.4 & 2.0 & 0.6 \\
\hline Scrub Land & 29.5 & 0 & 37.3 & 10.7 & 19.9 & 4.9 \\
\hline Residential Land & 10.6 & 0 & 1.4 & 13.4 & 10.1 & 67.6 \\
\hline Class Total & 100 & 100 & 100 & 100 & 100 & 100 \\
\hline Class Changes & 75.5 & 0 & 57.1 & 66.6 & 80.0 & 32.3 \\
\hline Image Difference & 223.0 & 23.9 & -55.6 & -24.3 & -65.5 & 15.8 \\
\hline
\end{tabular}

Table 7: Summer to Autumn Season Change Detection Percentage

\begin{tabular}{|l|l|l|l|l|l|l|}
\hline Class & Open Land & $\begin{array}{l}\text { Reservoir } \\
\text { Water }\end{array}$ & Forest & Waterway & $\begin{array}{l}\text { Scrub } \\
\text { Land }\end{array}$ & $\begin{array}{l}\text { Residential } \\
\text { Land }\end{array}$ \\
\hline Open Land & 77.5 & 4.6 & 1.6 & 32.4 & 28.5 & 24.9 \\
\hline Reservoir Water & 0 & 94.7 & 0 & 0 & 0 & 0 \\
\hline Forest & 0 & 0 & 73.6 & 0.5 & 2.3 & 0 \\
\hline Waterway & 0.9 & 0.6 & 0.1 & 53.0 & 2.3 & 2.7 \\
\hline Scrub Land & 8.5 & 0 & 24.3 & 4.6 & 60.1 & 13.2 \\
\hline Residential Land & 12.8 & 0 & 0.1 & 9.2 & 6.6 & 59.0 \\
\hline Class Total & 100 & 100 & 100 & 100 & 100 & 100 \\
\hline Class Changes & 22.4 & 5.2 & 26.4 & 46.9 & 39.8 & 40.9 \\
\hline Image Difference & 25.5 & -5.2 & -13.24 & -10.2 & -6.1 & -13.4 \\
\hline
\end{tabular}

\section{REFERENCES}

Almutairi, A., Warner, T. A., 2010. Change Detection Accuracy and Image Properties: A Study Using Simuated Data. In Remote Sens. 2, 1508-1529.

Czapla-Myers et al., 2015. The ground-based absolute radiometric calibration of Landsat 8 OLI. In Remote Sens. 7, 600-626.
Coppin, P., Jonckheere, I., Nackaerts, K., Muys, B., lambin, E., 2004. Review Article Digital Image change detection methods in ecosystem monitoring: A review. In Int. J. Remote Sens.25, $1565-1596$

Flood, N., 2014. Continuity of Reflectance Data between Landsat-7 ETM+ and Landsat-8 OLI, for both top-ofatmospheric and surface reflectance: A Study in the Australian landscape.In Remote Sens. 6, 7952-7970. 
Gardelle, J., Hieraux, P., Kergoat, L. and Grippa, M., 2010. Less rain, more water in ponds: A remote sensing study of the dynamics of surface waters from 1950 to present in Pastoral Sahel (Gourma Region Mali). In Hydrology and earth Sciences 14(2): 309-324. Doi:10.5194/hess-14-309-2010.

Hussain, M., Chen, D., Cheng, A., Wie, H., Stanley. D., 2013. Change detection from Remotely Sensed Images: From PixelBased to Object -Based Approches. In ISPRS J. Photogramm and remote Sensing 80 Doi:10.1016/j.isprs.2013.03.006.

Hecheltjen, A., Thonfeld, F., Menz, G., 2014. Recent advances in remote sensing change detection- A review. In Land Use and Land Cover Mapping in Europe. Manakos, I., Braun, M., Eds.; In Springer Netherlands: Dordecht, The Neterlands, pp. 145178 .

Irons, J. R., Dwyer, J. L., Barsi, J. A., 2012. The next Landsat satellite: The Landsat data continuity mission. In Remote Sens. Environ. 122, $11-21$.

Jiag, P. Li, Feng, Z., 2014. Cross-Comparison of Vegetation Indices Derived from Landsat-7 Enhanced Thematic Mapper (ETM_) and Landsat-8 Operational Land Imager (OLI) sensors. In Remote Sens. 6, 310-329.

Ke, Y., Im, J., Lee, J., Gong, H., Ryu, Y., 2015. Characteristics of Landsat 8 OLI-derived NDVI by comparison with multiple satellite sensors and in-situ observations. In Remote Sens. Environ.164, 298-313.

Knight, E., Kvaran,G., 2014. Landsat-8 operational land imager design, characterization and performance. In Remote Sens.6, 10286-10305.

Lu, D., Moran, E., and Hetrick, S., 2011. Detection of Impervious Surface Change with Multitemporal Landsat Images in an Urban-Rural Frontier." ISPRS J. Photogramm and remote Sensing, 66: 298-306. doi: 10.1016/j.isprsjprs.2010.10.010.

Morfitt, R., Barsi, J., Levy, R., Markham, B., Micijevic, E., Ong, L., Scaramuzza, P., Vanderwerff, K., 2015.

Landsat-8 Operational land imager (OLI) radiometric performance on orbit. In Remote Sens. 7, 2208-2237

Musci, L., Muladi, L., Henits, A., Farsang, Albrecht, V., 2014. Large scale UHI Mapping Based on Spatial Information Provided by Young Volunteers. In Carpathian Journal of Earth and Environmental Sciences 9 (2): 31-43.

Markham, B. L., et al., 2010. The Landsat data continuity mission operational land imager (OLI) radiometric calibration. In IEEE Int. Geoscience and Remote Sensing Symp. (IGARSS), pp. 2283-2286 (2010).

Markham, B., et al., 2014. Landsat- 8 operational land imager radiometric calibration and stability. In Remote Sens. 6, 1227512308.

Pehlevan, N., Schott, J. R., 2011. Investigating the potential of the operational land imager (OLI) for monitoring case II waters using a look-up-table approach. In Pecora 18: Forty Years of Earth Observation-Understanding a changing World, Herndon, VA.

Pervez, W., Valiuddin, Khan, S. A., Khan, J. A., 2016. Satellite-based land use mapping: comparative analysis of Landsat- 8 , Advanced Land Imager, and big data Hyperion imagery. In J. Appl. Remote Sens. 10 (2), 026004 (2016); doi: 10.1117/1.JRS.10.026004

Roy, D., et al. 2014. Landsat-8: Science and product vision for terrestrial global change research. In Remote Sens. Environ. $145,154-172$.

Seekell, D. A., and Pace., M. L., 2011. Does the Pareto distribution adequately describe the size sistribution of lakes? In Limnology and oceanography 56 (1): 350-356. Doi:10.4319/1o.2011.56.1.0350.
Schneider, A., 2012. Monitoring Land Cover Change in Urban and Peri-Urbanareas Using Dense Time Stacks pf Landsat Satellite Data a data Mining Approach. In Remote Sens. Environ, 124,: 689-704. Doi:10.1016/j.rse.2012.06.006.

Unger et al.J., 2010. Modelling of the Urban Heat Island Pattern Based on the Relationship between Surface and Air temperature. In Quarterly Journal of the Hungarian Meterlogical Service 114; 287-302.

U.S. Geological Survey, "Landsat Data Continuity Mission", U.S. Geological Survey, Washington, DC (2012).

Verpooter, C., Kutser, T. and Tranvik, L., 2012. Automated mapping of water bodies using Landsat multispectral data. In Limnology and oceanography methods10:10371050.Doi:10.4319/lom.2012.10.1037.

Yuan,F., Swaya, K. E., Loefffelholz, B. C., and Bauer, M. E., 2005. Land Cover Classification and Change Analysis of the Twin Cities (Minnesota) Metropolitan Area by Multi temporal Landsat Remote Sensing. In Remote Sens. Environ, 98, (23):317-328. Doi:10.1016/j.rse.2005.08.006.

Z. Zhang, Z., Dong, Z., Yan, C. and Hu., G., 2015. Change of lake areas in the southeastern part of China's Badain Jaran Sand Sea and its implications for recharge source. In Journal of Arid Land7 (1):1-9, doi:10.1007/s40333-014-0009-5. 